\title{
The appearance of ecological systems as a matter of policy
}

\author{
Joan Iverson Nassauer \\ Department of Landscape Architecture, 212 North Hall, 2005 Buford Avenue, University of Minnesota, \\ St. Paul, U.S.A. 55108
}

\begin{abstract}
Environmental policy should explicitly address the appearance of the landscape because people make inferences about ecological quality from the look of the land. Where appearances are misleading, failing to portray ecological degradation or ecological health, public opinion may be ill-informed, with consequences for environmental policy. This paper argues that while ecology is a scientific concept, landscape perception is a social process. If we do not recognize this difference, we have problems with the appearance of ecological systems. Three influential problems are discussed: 1) the problem of the false identity of ecological systems, 2) the problem of design and planning as deceit about ecological systems, and 3 ) the problem of invisible ecological systems. These problems for environmental policy may be resolved in part if landscape planners and policy-makers use socially-recognized signs to display human intentions for ecological systems. Specifically, planning and policy can include socially-recognized signs of beauty and stewardship to display human care for ecological systems. An example in United States federal agricultural policy is described.
\end{abstract}

Environmental policy should explicitly address the look of the land, not because aesthetic quality is coequal with biotic and physical quality of the landscape, though some have made this argument, but because the look of the land communicates. Kevin Lynch (1971) called the environment 'an enormous communications device'. What people see, and particularly our affective response to landscape, influences what we think belongs in the landscape. Policy can intentionally use this enormous communications device to suggest that patterns that support the ecological function of the landscape belong there, or policy can fail to address human interpretation of ecological patterns. Both the broadened concept of ecology that landscape ecology represents and the realities of the politics behind policy suggest that to ignore what the landscape communicates is naive. This paper explores the social dimen- sion of our perception of landscapes and suggests how that social dimension could inform environmental policy.

\section{The social dimension of perception}

The way things look is not always the way things are. This fact should be cause for consternation among those who are interested in the management of ecological systems. A highly functional landscape structure may go unnoticed - even by people who depend upon its function. People may change the landscape, destroy its ecological function, without even knowing what they have done. If we assume that people want to live in healthy ecological systems, the problem is that the way the landscape looks might not tell us whether the landscape 
is healthy or not. If we can see that the landscape is not healthy, we might do something about it. We might manage the landscape to improve its health. But we are unlikely to do that if we can't see it.

Why would we perceive a landscape as healthy when it is not? Or conversely, why would we perceive a landscape as unhealthy when it is not? One problem could be that we have a mistaken notion of what landscape health looks like; we have given ecological systems a false identity. Another problem could be that we are being deceived; we know what healthy ecological systems look like, but their true appearance is being masked by a misleading facade. Finally, ecological systems may be invisible; they exhibit no particular appearance for us to see.

Why should we have any of these problems with the appearance of ecological systems? Usually the way things look is the way things are. What we see is usually self-evident and it is interpreted with a shared social understanding. We might have problems with the appearance of ecological systems because their appearance is inconsistent with our shared social understanding of the way landscapes are supposed to look; healthy ecosystems might not match our social understanding of the desirable appearance of landscape. If we accept the fundamentally social nature of perception, we can learn something about the way we see ecological systems and about how we might manage the appearance of ecological systems.

\section{The problem of the false identity of ecological systems}

We identify nature with beauty, and of course, we identify ecological systems with nature. Consequently, we assume that healthy ecological systems are beautiful. But this syllogism misleads. Naturalness is a concept that has no specific appearance in form; it is a cultural concept determined by social process (Nash 1967; Nassauer 1979). When we identify ecology with nature, we fail to recognize the social dimension of our perception of nature as pristine beauty. Though we might see it that way, not everything that looks natural is pristine; it may not even be ecologically healthy. Furthermore, landscapes that are ecologically healthy may not look natural, at least not in the beautiful way that our social interpretation of nature demands. Nor are all healthy ecosystems pristine in the sense of being untouched by human action.

However, our identification of ecology with our social conception of nature leads us to expect healthy ecological systems to be beautiful. Some are, and luckily so, for the beauty of nature as articulated by Frederick Law Olmsted was a primary rationale for establishing the national park system (Nash 1967; Laurie 1979); in this case, beauty served ecology. But if we generalize from such prominent examples as the national parks to the landscape as a whole, we confuse our perceptions of natural beauty with ecological function.

Our identification of ecology with a particular interpretation of natural beauty, that is pristine nature, obscures the possibility that healthy ecological systems can display natural beauty without being pristine. When he proclaimed The End of Nature (1989), Bill McKibben failed to see this possibility. McKibben repeatedly points to threatened changes in human perception of nature to support his philosophical stance against human intervention in nature. Though much of his book surveys evidence and opinion about the inevitable biological and physical consequences of global warming, McKibben seems most profoundly affected by the way in which global warming and biotechnology have changed his perception of nature. The end of nature as he discusses it is not the end of ecological function, it is the end of a particular perception of natural beauty that depends upon the illusion that nature is distinct from humanity.

'... The death of (nature) begins with concrete changes in the reality around us - changes that scientists can measure and enumerate. More and more frequently, these changes will clash with our perceptions, until, finally, our sense of nature as eternal and separate is washed away, and we will see all too clearly what we have done' (p. 8, McKibben 1989).

McKibben abhors the 'domestication' of the earth because 'there's no such thing as nature anymore - that other world that isn't business and art 
and breakfast is now not another world, and there is nothing except us alone' (p. 89). He tells how William Bartram, an eighteenth century naturalist, explored the southeastern region of the United States and 'found vigorous beauty' in 'whatever direction he struck off in', how George Catlin's journal descriptions of the picturesque beauty of the frontier West form a baseline in his mind, 'a reminder of where we began'. McKibben's objection to 'rational management' of the wild is that it produces something that 'looks a lot like nature but isn't' (p. 168).

What makes the current crisis so intransigent to 'personal solutions' and finally sounds the death knell for nature says McKibben is that 'the greenhouse effect is the first environmental problem we can't escape by moving to the woods' (p. 204). McKibben's juxtaposition of the ideas of solution and escape are problematic. First, what does he mean by a personal solution? Certainly escaping to the woods doesn't solve any environmental problem. It only changes the perceptual evidence of the problem: out of sight, out of mind. Second, where is he escaping to? Did the woods ever provide a 'sense of nature as eternal and separate' from humanity? Only if one were oblivious to the shared social perception necessary for the woods to exist could one escape environmental problems by moving to the woods. In fact, McKibben's woods, the New York State Adirondack Park that he so lovingly describes, is a social pact, an agreement to manage a landscape in a particular way. The time for escape, if there ever was one, has long since passed.

McKibben's example of the woods that he admires as nature is a social construction. And his deep affection for the nature he sees in the woods suggests that this particular social construction is not a bad thing. What he was perceived there has contributed to his move to do something about ecological quality, to write a book called The End of Nature. The problem is that he does not incorporate the social basis for the woods into his argument for nature. Rather, he concludes that 'the comfort we need is inhuman'. He has given the nature he perceives a false identity.

Some who identify nature as separate from humanity may conclude with McKibben that ecological systems are best left unsullied by human action. Others who identify nature as separate may see this separation as license for unbridled use of ecosystems. Their view may lead them to intervene without respect for ecological function, making for human purposes different from McKibben's. While the sound of a chain saw buzzing in the Adirondack woods intrudes upon McKibben's feeling that he is in 'another, separate, timeless, wild sphere' (p. 47), the person using the chain saw may very well share McKibben's sense of the woods as separate from humanity - only 'humanity' is where the person cutting timber lives. Whatever destruction may be perpetrated there will be left behind when the timber is hauled out of the woods. Once again, out of sight, out of mind. McKibben may wish to escape to the woods, but this person will escape from the woods, objecting to ecological degradation only if it appears in his or her own backyard.

The chain saw operator and McKibben in the 'separate, timeless, wild sphere' represent equally logical but philosophicaly opposed implications of the problem of the false identity of ecological systems. It follows that once separate from nature, we human beings may choose either to degrade or deify what we see as distinct from ourselves.

\section{The problem of design and planning as deceit about ecological systems}

If we walked through the woods with McKibben to where the chain saw was buzzing and saw the timber harvest site, would it be beautiful? Would it look natural? Probably not. If we share McKibben's sense of nature in the woods, we might be happier if we hadn't taken the walk at all. We might be happier still if the chain saw were equipped with a completely effective muffler. The effect would be the protection of our illusions. Protection of illusions can be called deceit.

Perhaps in his perception of the woods, McKibben is only one of the 'gullible public' (in the words of Denis Wood, 1988), a victim of some design or planning expert's intention to deceive the viewer about the real human purpose or history of the 
woods by masking what is really there. Wood delivers a highly-charged critique of the federal government land-managing agencies' visual management systems (USDA 1973-85, USDI 1975, USDT 1976-79) as tools for severing ecological reality from landscape appearance. He points to the visual management systems' aim to conceal the logging, grazing, mining, and resort development that occur on federal lands by designing such activities so that they 'blend' with their natural surroundings. Such dissembling with form he terms a lie. 'The point is not the resource use, but the lying about it, not the cutting down of trees, but the attempt to pretend we didn't do it (it was the wind, it was the rockslides, it was the fire).' Rather he suggests that design and management should tell the truth. Doing so 'will force us to accept responsibility for our desires' (p. 203, Wood 1988).

Though the New York State Adirondack Park would not have been managed with federal visual management systems, it was established and has been managed with the same picturesque conventions that they only make explicit (Nash 1967; Adirondack Park Agency 1979; The Commission on the Adirondacks 1990). Since the Industrial Revolution, the dominant Western landscape design convention has been the picturesque, an ideal articulated in the 17 th century by Alexander Pope as the beauty of 'nature methodized' (Pevsner 1944). The idea has been so powerful that it has evolved and been integrated into cultural norms for landscape appearance, not as an idea about nature but as a 'frozen' icon, unreflectively perpetuated (Howett 1987). Sidney Robinson explains that 'we owe to the 19th century the confusion that a case of mistaken identity perpetrated by a picturesque landscape is the same as being natural,' where he means 'natural' as being 'privileg[ed] ... as nature's way' (p. 9, 1990). In fact, Humphrey Repton's description of the four key principles of his art in his 'Enquiry into the Changes of Taste in Landscape Gardening' (1806) spells out the means of confusion: 'First, it must display the natural beauties and hide the natural defects of every situation; secondly, it should give the appearance of extent and freedom, by carefully disguising or hiding the boundary; thirdly, it must studiously conceal every interference of art, however expensive, by which the scenery is improved; making the whole appear the production of nature only; and fourthly, all objects of mere convenience or comfort, if incapable of being made ornamental, or of becoming proper parts of the general scenery, must be removed or cancelled ...' (Clifford 1963).

The picturesque image of nature has become part of western culture to such a degree that it is frequently mistaken for nature, making the 'method' of the plan or design invisible but the effect of the design expected. Robinson warns that 'appeals to the circumstantial appearance of nature as the justification for a landscape aesthetic are rhetorical gestures, not the guarantee of truth' (p. 9, 1990). We should not expect the 20th century picturesque we have received to be about truth but about rhetoric, and shared social meaning. In fact, the visual management systems that Wood so sharply criticizes are clear in their statement that they are intended to produce an 'expectedimage', particularly for tourists, not to reveal ecological reality, which may contradict social expectations (McGuire 1979). The visual management systems are a form of rhetoric. They are grounded in a social concept, that which constitutes an aesthetically pleasing environment.

When the United States National Environmental Policy Act (1969) dictated that federal actions would 'assure for all Americans ... aesthetically and culturally pleasing surroundings', federal agencies made the picturesque image explicit. These explicit statements and the burgeoning ecological awareness of the time startled landscape scholars into reflecting upon our assumptions. The systems spelled out the desirability of hiding landscape functions that might be perceived as unattractive behind a hill, out of the viewshed. They clarified our social expectation of nature, where what clearly isn't nature (a building or a logging pattern) has at least been made to look like it.

At the same time as the visual management systems were being implemented, toxic chemicals were being dug from school grounds in New York and animal species were becoming endangered in national forests managed for aesthetic quality. As social consciousness of unseen ecological systems 


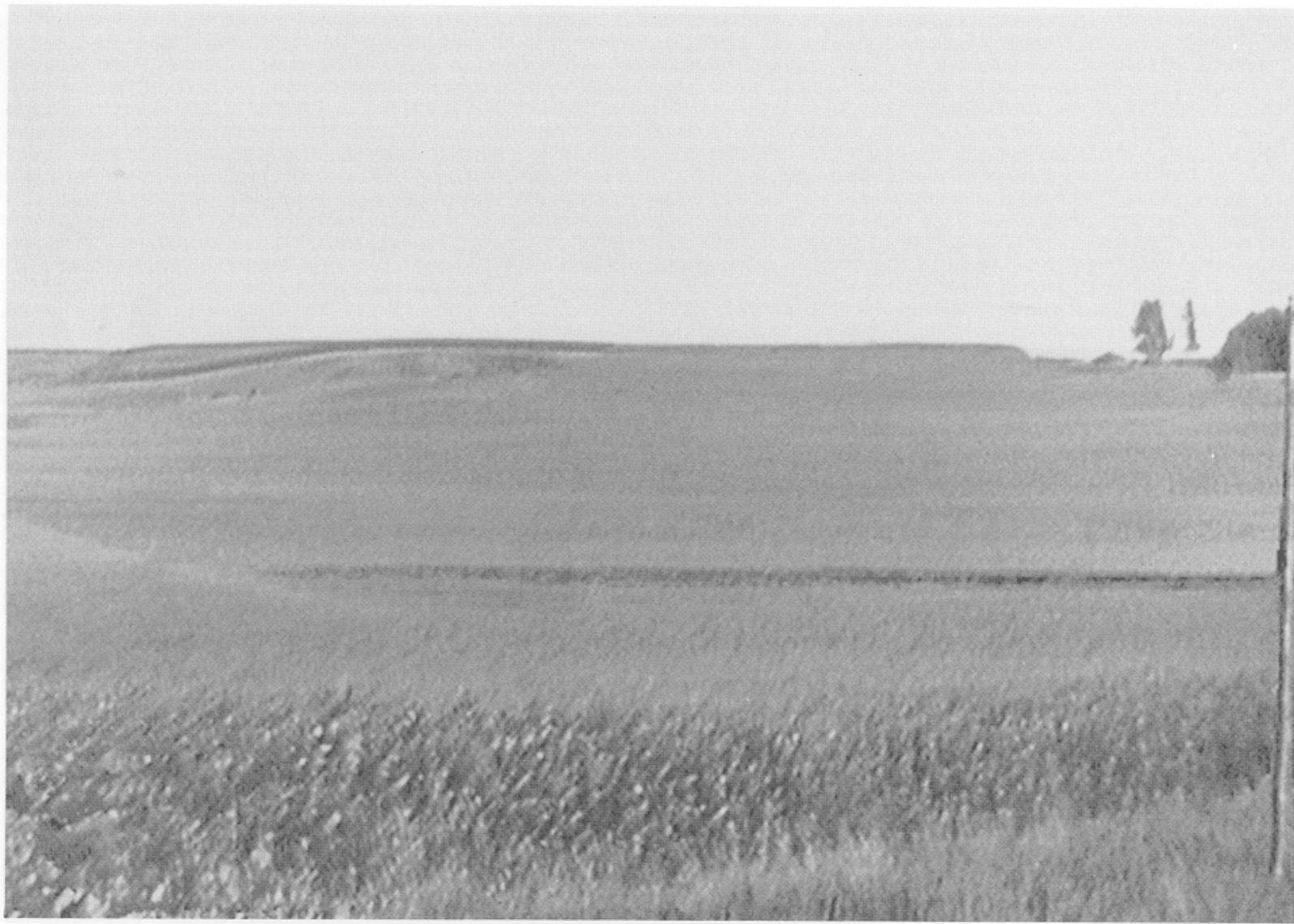

Fig. 1. Agricultural field eligible for the federal Conservation Reserve Program as they would look when managed for maximum corn production regardless of ecological effect.

changed, the visual management systems took on a sinister cast. Landscape scholars were unavoidably confronted with the difference between ecological systems and picturesque nature, the nature that McKibben has enjoyed.

The visual management systems didn't sever the appearance of the landscape from ecological reality. They simply spelled out a cultural norm in which the appearance of nature was only coincidentally related to ecological reality. The severing that has occurred, at least for critics and scholars, is of the picturesque. The picturesque has been severed from the landscape. This severing has forced many of us to seek a new position, along with Wood, on higher ground. We have begun to argue that the picturesque is superficial at best and often unethical, in that it prevents us from seeing what Wood suggests we should be forced to see, the ecological con- sequences of our actions. Voices have been raised in calls for a new ecological aesthetic (e.g., Koh 1982, 1988; Spirn 1988; Thorne 1991).

\section{The problem of invisible ecological systems}

What would the landscape transformed by a new ecological aesthetic look like? Landscape architects seeking an ecological aesthetic have been inspired by the work of environmental artists, who John Beardsley suggests in his survey of Earthworks and Beyond (1984) 'reveal the world to us anew'. This same word 'reveal' occurs again and again as advocates of a new ecological aesthetic discuss what we should be doing. Reveal means 'to lay open to view, to display, to exhibit' (Random House Dictionary of the English Language, 2nd ed. 1987). To con- 


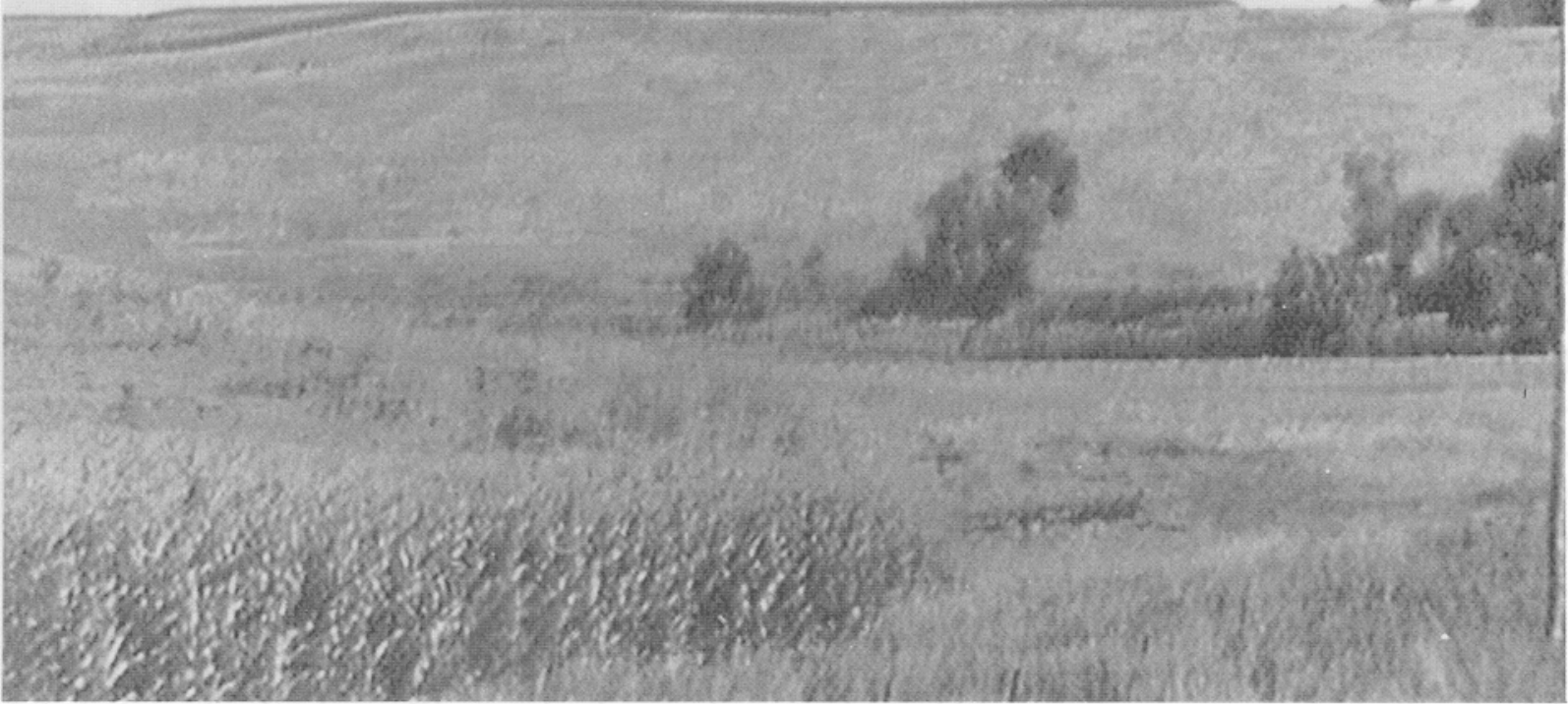

Fig. 2. The same fields as they would look if enrolled in the federal Conservation Reserve Program, planted with seed mixes recommended for this region by the United State Department of Agriculture.

strue the task of design as revealing ecological systems implies that ecological systems are visible. Yet the carbon cycle is not visible, sheet erosion is not visible, toxic chemicals in water often are not visible, the North American flyway is only partially visible, and so on. How will we be forced (Wood's word) to see these ecological phenomena?

Robert Thayer (1989) says that we should make one aspect of ecological function, sustainability, conspicuous in design. If something is conspicuous, we cannot fail to see it. But how are we to do this? What will people notice? How can we be sure they get the right message, an accurate understanding of ecological systems at work? Thayer suggests that art provides the method for making sustainability conspicuous. He calls for 'artful interpretation of the human/land relationship' because 'art has the ability to anticipate society' (p. 108). Thayer shares with Howett (1987) the assumption that art has a special ability to show us what we don't yet perceive but eventually will see. Such an assumption fails to scrutinize art. Art operates within its own traditions. It is not necessarily reliable in communicating the truth of ecological function; nor is art necessarily intended to make ecological function conspicuous.

Marcia Eaton's analysis suggests a more reliable approach. She reminds us that 'One can communicate only with an already existent language and cultural sign system' (p. 23, 1990a). Working from the tenets of linguistic philosophy, she advises us to describe the landscape in recognizable terms, which are rooted in shared social perceptions. She recommends that new landscape appearances stretch meanings rather than to impose or force them. In her book Aesthetics and The Good Life (1990b), 


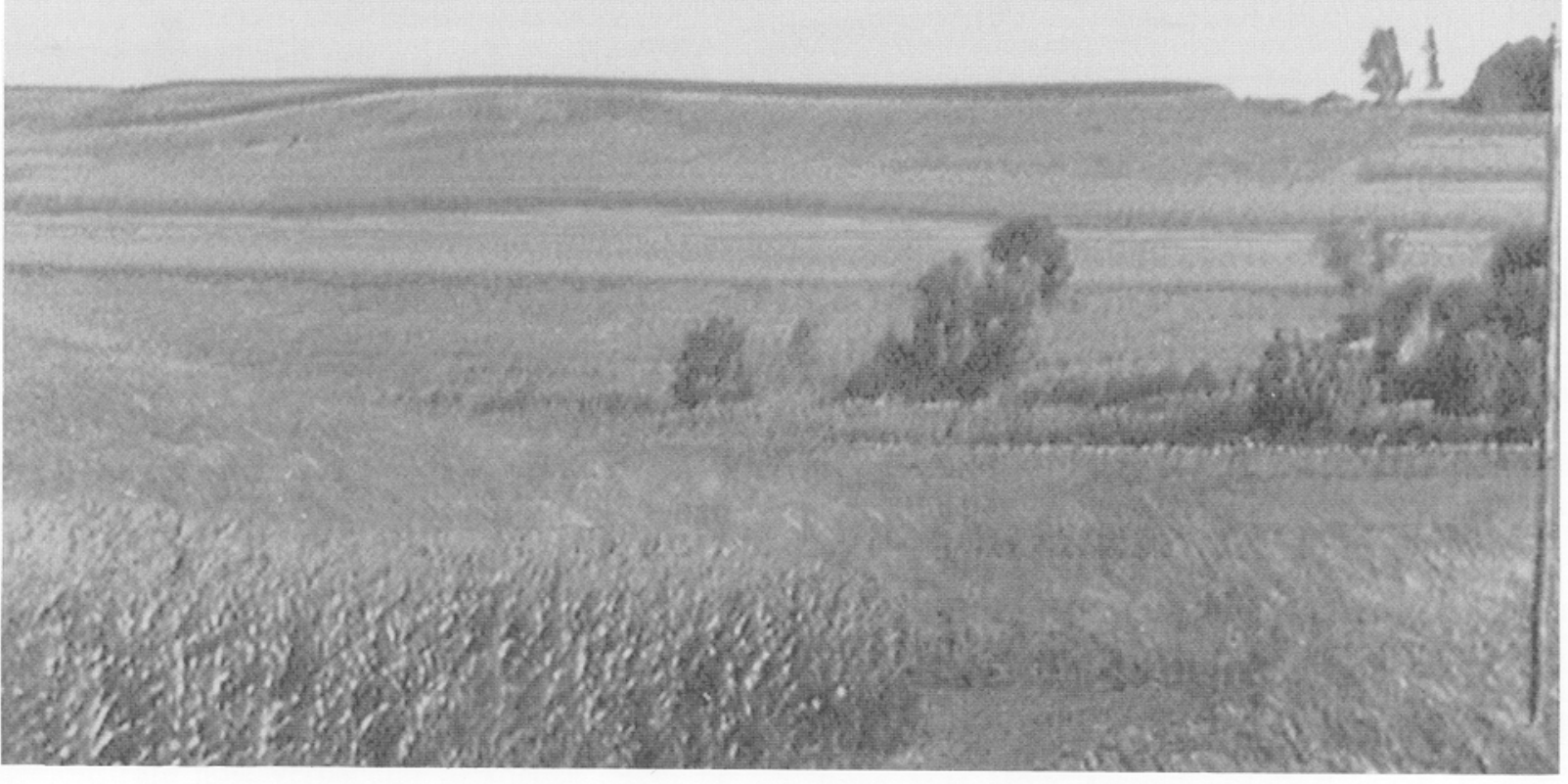

Fig. 3. One alternative for accommodating crop production and ecological objectives, including habitat enhancement. This landscape is likely to be attractive to local people. Vernacular landscape elements that are associated with landscape care (mown strips, forbes) are used to portray the good stewardship represented by perennial cover, a landscape element that might be misunderstood as a lack of care. Stripcropping in the background also communicates good stewardship.

Eaton describes that perceptions of natural beauty are 'based upon traditions, and thus are not arbitrary, as has often been maintained. That some features are relevant [to aesthetic perception] is determined traditionally. And they provide a base for real argument and for the possibility of coming to agreement. Speaking the same language assures that there will be a basis for agreement' (p. 119). The pragmatic implication of Eaton's argument is that landscape policy and design should use the cultural vocabulary of landscape aesthetics to communicate ecological function.

Regardless of the ethical (or moralistic) arguments for skirting cultural norms and imposing aesthetic values to make us see ecological function, we must be skeptical of the efficacy of any ap- proach that ultimately implies a Utopian or elitist conception of art. Eaton is careful to define tradition as deriving from community values not elite dictates. She also clarifies that traditions change but not all at once. Our perceptions of nature and the association of the appearance of nature with ecological systems are rooted in social process. While we may think our ecological purposes ethical in contrast to theirs, the Stalinist Soviet imposition of Socialist Realism, the Maoist 'Cultural Revolution' and certain phases of the French Revolution, as described by Maynard Solomon (1974), all attempted to use art as pedagogy. Solomon characterizes the art of these post-revolutionary periods as: (1) insisting on the creation of a body of exemplary myths, (2) rejecting complexity, and (3) im- 


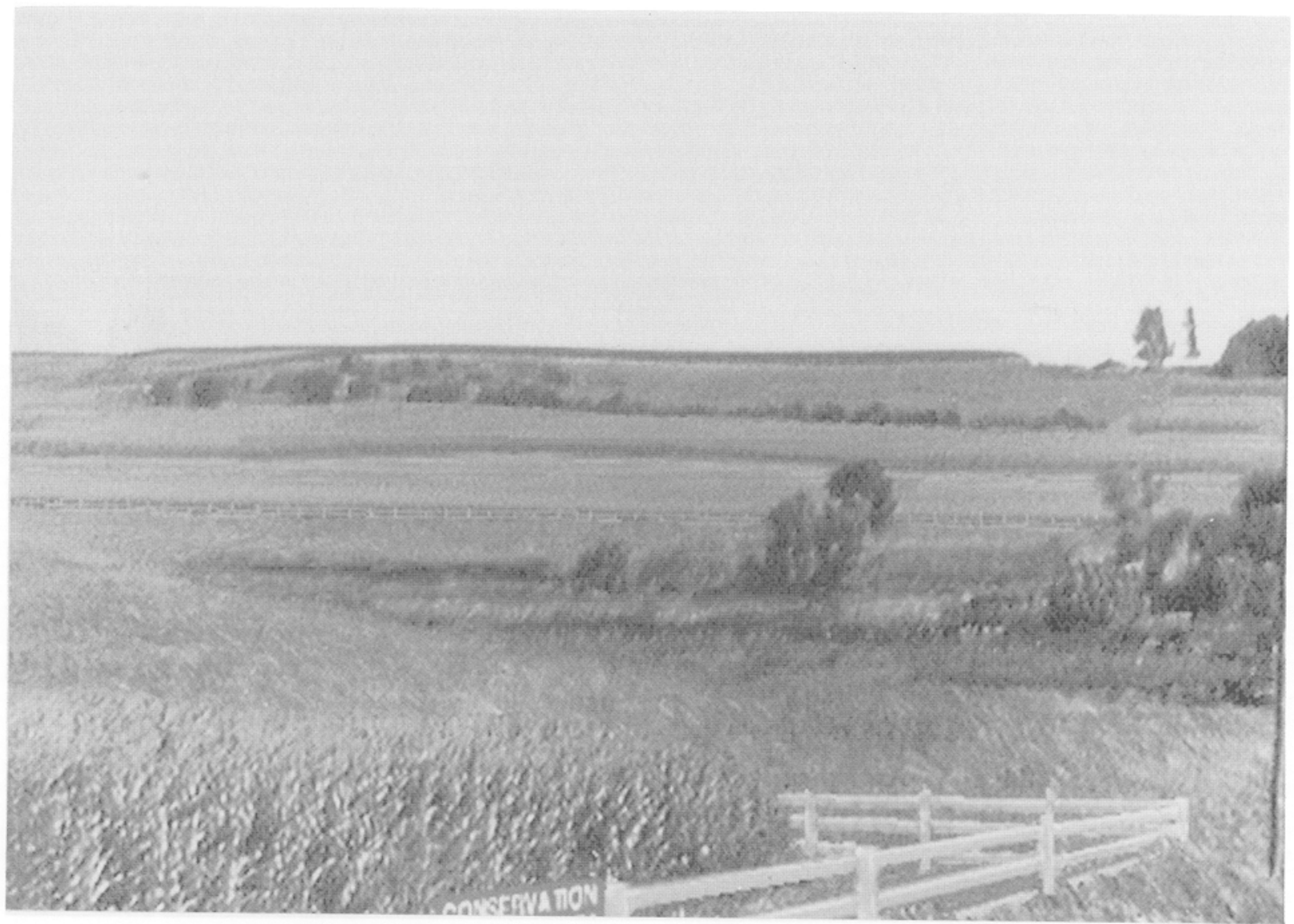

Fig. 4. A second alternative for accommodating crop production and ecological objectives in a way that is likely to be perceived as attractive: the white fence around the wildlifearea and a sign on the fence communicate human intention to care for this habitat.

posing censorship. These characteristics stand as warnings to us as we emerge from our particular revolution poised to use landscape design to teach about ecology. Having torn down the banner of the picturesque, we should be wary of hoisting another one into its place. Ecological systems can be made visible in different ways in different times and places.

\section{Social signs with ecological purposes}

If ecological systems have a false identity when they are confused with an ideal of beautiful nature, if the picturesque is no longer tenable in a world where unseen ecological threats have entered the popular consciousness, yet ecological systems have no identifiable image of their own, what are we left with? We are left with an evolving language of landscape aesthetics, a vernacular language of form by which people identify what does or does not belong in their landscape, what is beautiful and what is ugly.

The power of the picturesque as an unarticulated cultural norm teaches us that the way to communicate the ecological function of the landscape is to embrace the social nature of our landscape perception. If we probe the social language of landscape form and learn the conventions of landscape appearance, we can use these conventions to label ecological functions. By intentionally using the conventions, we create the possibility that the conventions themselves will change. Our shared social perceptions of landscape beauty may adapt to include landscape features that are necessary to ecological health.

This conclusion assumes that aesthetic perceptions grow out of the evolving response of a com- 


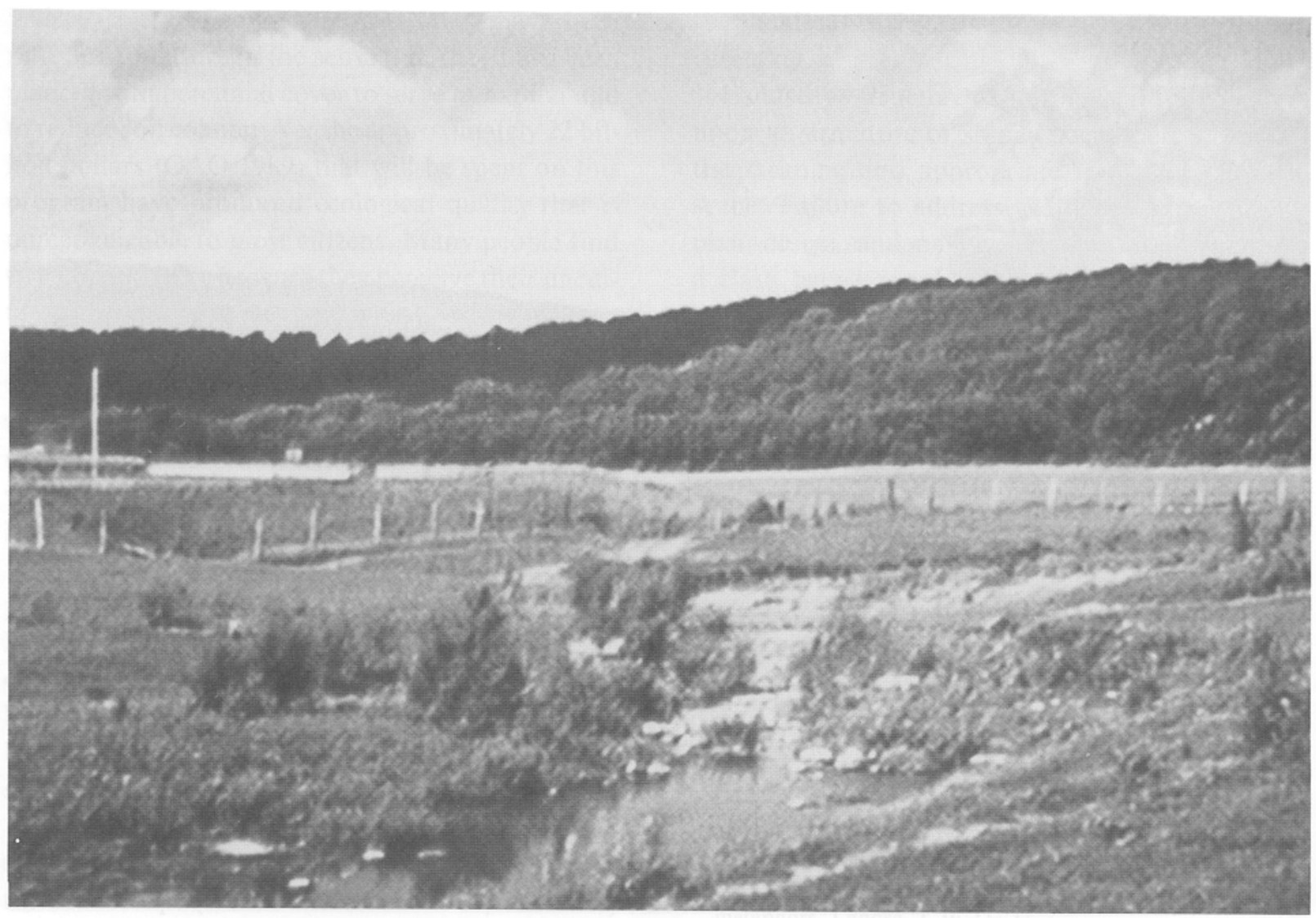

Fig. 5. On a different site, a stream is shown in an overgrazed pasture.

munity, they are not forced or dicated. There is no ecologically-correct landscape aesthetic, one that may be good for us but does not feel good. It is possible for the aesthetic language of a community to speak to ecological systems, and over time to be changed by that speech. The idea is to make ecological systems popularly understood by using a vernacular language of landscape aesthetics to portray (not just reveal) ecological systems. It implies using widely understood picturesque conventions without the picturesque intentions of blending and concealing. It means making evident the method of nature methodized. It also implies going beyond the picturesque to probe other powerful vernacular aesthetics.

One such vernacular aesthetic that is rooted in the evidence of human intention is the aesthetic of stewardship. In the aesthetic of stewardship, people form the landscape to display themselves as care- takers of nature (Nassauer 1986, 1988a, 1988b). To protect and enhance ecological health, we should not remove signs of human intervention from the landscape, as McKibben would prefer. Rather we should insert signs of our human presence as caretakers of landscapes that embody healthy ecological systems. For McKibben, any sign of humanity detracts from nature; it implies an arrogant belief in our ability to control. For Wood, stripping away the picturesque to reveal the actual purposes of humanity is only good medicine; it would force us to see what we are doing. Neither argument recognizes that we protect ecological systems by putting our human stamp upon them, by clearly showing our intention for them to exist.

Human perception of landscape is not really perception of landscape, at least not completely. It is also the perception of other human beings' relationship to that landscape, as owners, caretakers, 


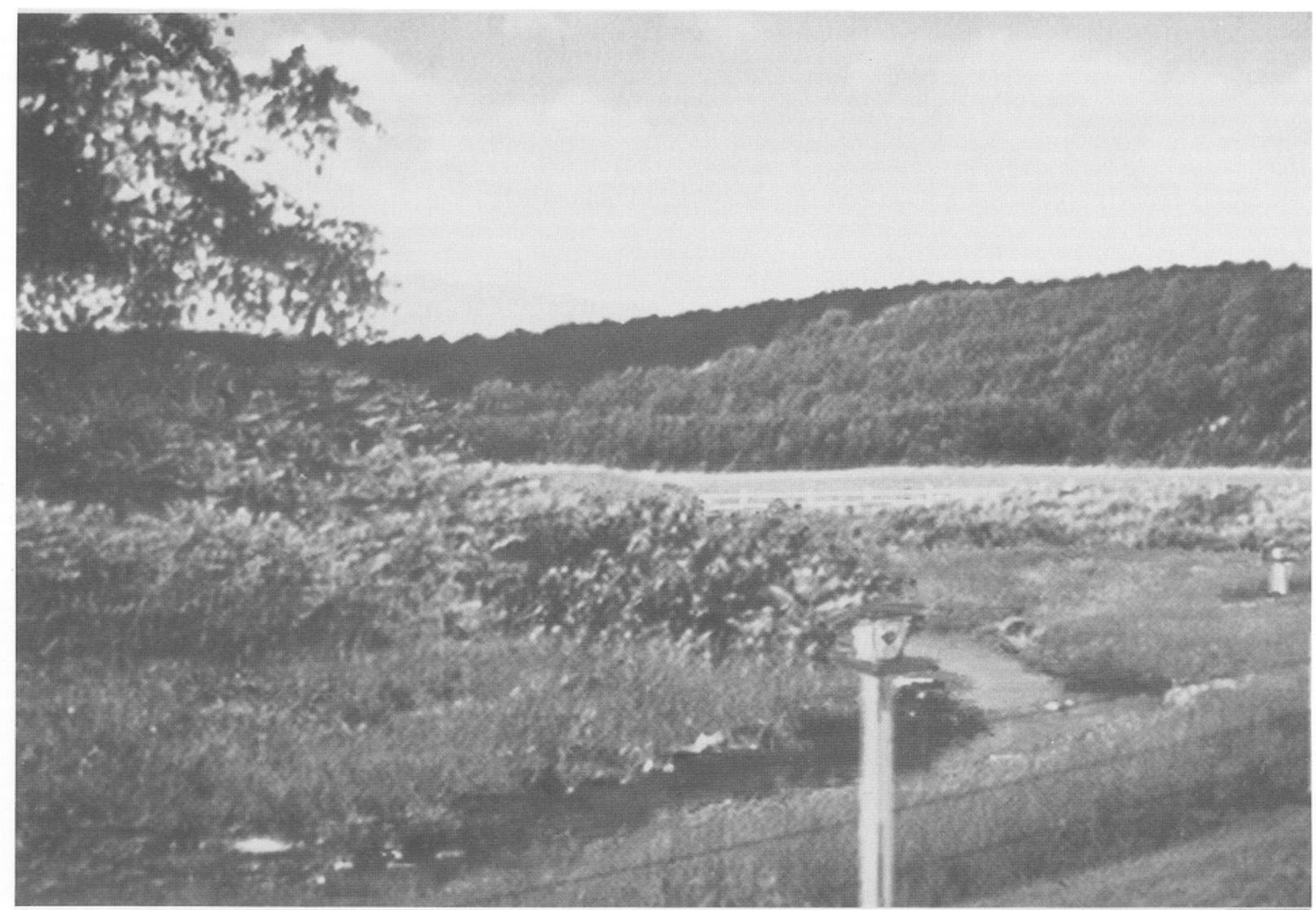

Fig. 6. A computer simulation of a stream restoration project on the same site demonstrates the effect of vernacular signs of landscape care (mown strips, forbes, white structures).

viewers, users, as people having some intention for the land (intentions could be anything from having a 'nice yard' to maintaining habitat for black panther). Human intention can support ecological function by bringing it into the sphere of human perception. When we intervene in landscape by policy or design we should be aware of what intentions the appearance of the landscape communicates. If people can see that a forest thick with undergrowth is intended to be a wildlife preserve, they will treat it differently than if they see it as an undeveloped woodland with no particular function, at least as intended by people. Conversely, the Silphium that Aldo Leopold so admired in an unmown corner of a country cemetery (Leopold 1966) had little chance of surviving a thorough caretaker; there was nothing about the design of the cemetery to suggest that the flower or the prairie grasses surrounding it were intended to be there. The general principle that we can use to guide design and policy is to label ecological function with socially-recognized signs of human intentions for the landscape, setting expected characteristics of landscape beauty and care side by side with characteristics of ecological health.

\section{An example with policy for agricultural land}

Finally, an example in the rural Midwest shows how labelling with socially-recognized signs might work. The example begins with federal policy for agricultural land established in the 1985 Food Security Act. Under Title 12 of the Act, 34 million acres of formerly cultivated land have been returned to nature, at least for ten years, as part of the Conser- 
vation Reserve Program (CRP). They have been returned to nature in the sense that they have been planted with perennial cover to serve as habitat and to reduce soil erosion. Yet the approximately 22 billion dollars (GAO 1989) that will be spent on this program have produced ecological quality that is unrecognizable to most citizens. Many people find CRP parcels ugly because they perceive their uncultivated cover as weedy or neglected. Federal policy makers were oblivious to the opportunity for using these 34 million acres as 'an enormous communications device'. They did not attempt to hide the CRP (no picturesque problems here). They simply revealed it without any consideration for the vernacular language of landscape aesthetics which the farmer participants in the CRP program and the public employ when they drive through the rural landscape. A better approach would have been to design CRP parcels to portray their ecological benefits. Vernacular characteristics of landscape beauty could have been used to label the good stewardship that CRP lands embody.

The accompanying computer-based landscape simulations of a southeastern Minnesota agricultural landscape (Pitt and Nassauer 1989; Pitt 1990) demonstrate how vernacular aesthetics might be used to portray the ecological quality of agricultural landscapes where soil and water conservation and habitat enhancement practices are implemented (Figs. 1-6). They are presented here to illustrate the range of possible appearances of ecological systems and to suggest the potential for aesthetic language to help us see ecological value.

\section{Conclusions}

If we can manage the appearance of landscape to show that ecological functions are intended by human action, we defend them against other kinds of ecologically misdirected, even if well intended, human 'improvements'. If we design and maintain landscapes, from wilderness preserves to small environmental resource patches, to show that they are not leftover or simply undeveloped, and that someone stands behind their existence, we force them to become the topic of social discourse. An affront to the landscape then becomes an affront to its caretaker.

Landscape structure and ecological function rest upon an armature of shared social perceptions of the meaning and appropriate treatment of landscape. Failure to address these perceptions as we plan, design, and manage the landscape will assure a clash between public perception of nature and public action on behalf of ecological function. Rather we can use our shared language of landscape perception to enable people to see and defend the ecological systems upon which they depend.

\section{References}

Adirondack Park Agency. 1979. A Citizen's Guide to Adirondack Park Agency Land Use Regulations. Adirondack Park Agency. Ray Brook, New York. 24 pp.

Beardsley, J. 1984.Earthworks and Beyond: Contemporary Art in the Landscape. Abbeville Press, New York. 144 pp.

The Commission on the Adirondacks. 1990. The Adirondacks Park in the Twenty First Century. State of New York. 96 pp.

Clifford, D. 1963. A History of Garden Design. Praeger, New York. 232 pp.

Eaton, M.M. 1990a. Responding to the call for new landscape metaphors. Landsc. J. 9: 22-27.

Eaton, M.M. 1990b. Aesthetics and the Good Life. Farleigh Dickinson University Press, London. 209 pp.

Howett, C. 1987. Systems, signs, sensibilities: Sources for a new landscape aesthetic. Landsc. J. 6: 1-12.

Koh, J. 1982. Ecological design: A post-modern design paradigm of holistic philosophy and evolutionary ethics. Landsc. J. 1: 76-84.

Koh, J. 1988. An ecological aesthetic. Landsc. J. 7: 177-191.

Laurie, M. 1979. A history of aesthetic conservation in California. Landsc. Plan. 6: 1-49.

Leopold, A. 1966. A Sand County Almanac. Oxford University Press, New York. 296 pp.

Lynch, K. 1971. Site Planning. Second ed. MIT Press, Cambridge. $384 \mathrm{pp}$.

McGuire, I. 1979. Managing the forest landscape for public expectations. In Our National Landscape: A Conference on Applied Techniques for Analysis and Management of the Visual Resource. pp. 16-18. USDA Forest Service General Technical Report PSW-35, Berkeley, CA. 752 pp.

McKibben, W. 1989. The end of nature. Random House, New York. 226 pp.

Nash, R. 1967. Wilderness and the American mind. Yale University Press, New Haven. 425 pp.

Nassauer, J. 1979. Managing naturalness in wildlands and agricultural landscapes. In Our National Landscape. pp. 447-453. USDA General Technical Report PSW-35, Pacific 
Southwest Forest and Range Experiment Station, Berkeley. Nassauer, J.I. 1986. Caring for the countryside. Publication AD-SB-3017. University of Minnesota Agricultural Experiment Station, St. Paul. 48 pp.

Nassauer, J.I. 1988a. 'The aesthetics of horticulture: Neatness as a form of care.' Hort. Sci. 23: 973-977.

Nassauer, J.I. 1988b. 'Landscape Care: Perceptions of Local People in Landscape Ecology and Sustainable Development.' Landscape and Land Use Planning 8: 24-37. American Society of Landscape Architects, Washington, D.C.

Pevsner, N. 1944. The genesis of the picturesque. Arch. Rev. 96: 139-146.

Pitt, D.G. and Nassauer, J.I. 1989. The Use of Image Capture Technology and Geographic Information Systems to Integrate Landscape Values into Public Policy: Six Case Studies. Landscape and Land Use Planning 9: 44-58. American Society of Landscape. Architects, Washington, D.C.

Pitt, D.G. 1990. Developing an image capture system to see wilderness management solutions. In Managing America's Enduring Wilderness Resource. pp. 541-548. Edited by D.W. Lime. University of Minnesota, St. Paul. 706 pp.

Random House Dictionary of the English Language. Second Edition. 1987. Random House, New York. 2426 pp.

Robinson, S.K. 1990. The picturesque in an ancient Japanese novel. Landsc. J. 9: 9-15.

Solomon, M. 1974. Marxism and Art. Vintage Books, Random House, New York. 649 pp.
Spirn, A.W. 1988. The poetics of city and nature: Towards a new aesthetic for urban design. Landsc. J. 7: 108-126.

Thayer, R.L., Jr. 1989. The experience of sustainable landscapes. Landsc. J. 8: 101-110.

Thorne, J. 1991. An Ecological Aesthetic. In Landscape and Urban Planning.

Wood, D. 1988. Unnatural illusions: Some works about visual resource management. Landsc. J. 7(2): 192-205.

U.S. Department of Agriculture. 1973-85. National Forest Landscape Management, Volume 1, Agriculture Handbook 434; National Forest Landscape Management, Volume 2, Chapter 1: The Visual Management System. Agriculture Handbook 462; Chapter 2: Utilities. Agriculture Handbook 478; Chapter 3: Roads. Agriculture Handbook 483; Chapter 6: Fire. Agriculture Handbook 608; Chapter 7: Ski Areas. Agriculture Handbook 617. Forest Service, USDA, Washington, D.C.

U.S. Department of Agriculture. 1978. Procedure to Establish Priorities in Landscape Architecture. Technical Release 65. USDA Soil Conservation Service, Washington, D.C.

U.S. Department of Interior. 1975. Visual Resource Management: BLM Manual. Bureau of Land Management, Washington, D.C.

U.S. General Accounting Office. 1989. Farm programs: Conservation research program could be less costly and more effective. GAO/RCED-90-13. U.S.G.A.O. Gaithersburg, Maryland. $79 \mathrm{pp}$. 